\title{
Kosovo: Lang rejse mod selvstændighed
}

\section{Søren Jessen-Petersen}

\section{Kosovo er et selvstændigt land, men det holdes stadig uden for FN, blandt andet fordi fem EU- lande nægter at anerkende dets selvstændighed. Både Kosovo og EU bør tage sig sammen}

I september i år tog Kosovo det endelige skridt på den lange rejse mod uafhængighed. Den internationale landegruppe, deriblandt Danmark, der har overvåget opfyldelsen af betingelserne for at hæve den kontrollerede selvstændighed, besluttede på et møde i Pristina, at Kosovo havde opfyldt alle betingelser. Overvågningen blev iværksat på anbefaling af FN's mægler for Kosova, den tidligere finske præsident, Martti Ahtisaari.

Beslutningen, der betyder, at Kosovo nu er uafhængigt, blev taget fire år efter landets egen selvstændighedserklæring og 15 år efter, at Kosovos oprørsbevægelse, UCK, startede den væbnede kamp mod serbiske styrker, og 13 år efter, at NATO greb ind og satte en stopper for den serbiske udrensningsproces i Kosovo.
I 1999 blev NATOs aktion fulgt op af FN's mission i Kosovo (UNMIK), der skulle styre området i en overgangsperiode, indtil den endelige status for Kosovo kunne besluttes.

Kosovo står nu endelig på egne ben. De politiske ledere kan ikke længere skjule sig bag de internationale repræsentanter, når vanskelige beslutninger skal tages. Nu må de politiske institutioner alene tage ansvaret, og med ansvaret følger ansvarlighed. Det slap de behændigt uden om tidligere ved at skyde skylden for fejlagtige beslutninger og handlinger eller mangel på samme på de internationale repræsentanter.

Mens Kosovo trods alt bevæger sig fremad, står Serbien i stampe. I Beograd synes en betydelig del af den politiske proces at være blevet gidsel for den stædige politik omkring Ko- 
sovo. For flertallet af befolkningen er Kosovo ikke længere en vigtig prioritet i sammenligning med økonomi og beskæftigelse, men de politisk ansvarlige synes hverken at følge flertallet eller at have modet og visionen til at frigøre sig fra den hårde linje om Kosovo.

Mange ansvarlige politikere har gjort det klart, deriblandt præsident Tomislav Nikolic, at Serbien aldrig anerkender Kosovos selvstændighed, og seneste har han erklæret, at hvis valget står mellem optagelse i $\mathrm{EU}$ og at opgive kravet på Kosovo, så står Serbien hellere uden for EU.

Serbien har vanskeligt ved at bevæge sig videre uden at 'vinde Kosovo tilbage', mens Kosovo bevæger sig fremad uden Serbien, men har dog klart forstået, at venskabelige relationer med Beograd ville bidrage til yderligere fremskridt. For at normalisere og stabilisere uafhængigheden og for at mindske eller fjerne de mange destabiliserende aktioner styret fra Beograd har Kosovo brug for en konstruktiv dialog med Serbien.

Dialogen omkring såkaldte tekniske emner, blev påbegyndt under EU's initiativ for mere end et år siden, men blev suspenderet tidligere på året, da Serbien forberedte sig til valg. Serbiens interesse i dialogen synes at være ønsket om EU-medlemskab og, uden at det er blevet sagt direkte, måske håbet $\mathrm{om}$, at spørgsmålet om Kosovos status kan blive genoptaget i en eller anden form. Kosovo ønsker normale bilaterale relationer med Serbien, men forsøger også at få dialogen fremstillet som en slags serbisk anerkendelse af Kosovo. Og disse to udgangspunkter spænder gang på gang ben for dialog og fremskridt.

\section{Ringe dialog med nord}

Det største problem er uden tvivl situationen omkring det nordlige Kosovos status. I den del af Kosovo er der en klar serbisk majoritet, og regeringen i Pristina har enorme vanskeligheder med at etablere sig som suveræn myndighed i regionen.

De serbisk dominerede politiske institutioner accepterer kun politiske instrukser fra Beograd. Samtidig bruger Beograd Kosovo-serberne som en kynisk brik i de fortsatte forsøg på at destabilisere Kosovo. Og endelig har de politiske instanser i Pristina aldrig overbevist omverdenen om, at man virkelig ønsker at have det nordlige Kosovo som en del af landet. Hjernen og retorikken er klar, når man gang på gang fastholder, at den nordlige del også er en del af Kosovo, men jeg har altid tvivlet på, at hjertet også er overbevist.

De talrige forsøg, jeg gjorde i min tid som FN's Særlige Repræsentant i Kosovo, for at få Pristina til at vise ikke blot i ord men også i handling, at man var parat til at engagere sig $i$ forsoningsprocesser med Kosovoserberne og på samme tid hjælpe 
med den økonomiske udvikling, blev for det meste mødt med mindre end halvhjertede svar. Resultatet var, at de beskedne invitationer til dialog med mere konstruktive serbere i nord aldrig fik den opfølgning, som muligvis kunne have fået en lokal dialog i gang.

Det var netop de modstridende interesser i Pristina og Beograd omkring situationen i nord, der motiverede Ahtisaari til at foreslå udstrakt selvstyre i den nordlige del af Kosovo, da han fremlagde sit omfattende forslag til løsning af Kosovos status. Ifølge Ahtisaari skulle det serbiske mindretal i den region have ret til fortsatte direkte relationer med Beograd, specielt med henblik på økonomisk hjælp, men også have normale kontakter med Pristina.

Ahtisaari handlede også på baggrund af gentagne forsikringer fra den internationale kontaktgruppe af lande, der støttede statusprocessen, at deling af Kosovo og en tilbagevenden til situationen før 1999 var udelukket. Så Ahtisaaris forslag var det mest logiske, og det eneste, der burde kunne fungere på sigt.

Normalisering og konsolidering af selvstændigheden kræver blandt andet, at Kosovo kan deltage i internationale organisationer, som enhver anden selvstændig stat. På det område har landet dog nogle alvorlige problemer, som ikke er selvforskyldte. Ahtisaaris plan om uafhængighed blev først bakket op af FN's generalsekretær Ban Ki-Moon, der derefter skiftede mening, da det blev klart, at Rusland ikke ville acceptere planen. Russernes modstand skyldtes naturligvis, at vennerne i Beograd var fundamentalt imod Ahtisaaris forslag om kontrolleret selvstændighed. Men også, som Ruslands udenrigsminister Sergej Lavrov tidligere fortalte mig, at Moskva havde sine egne prioriteter, de georgiske løsrivelsesregioner Abkhasien og Sydossetien, som Rusland sammen med enkelte andre lande siden har anerkendt som selvstændige stater.

Ruslands trussel om at nedlægge veto i FN's Sikkerhedsråd mod Ahtisaaris plan betød, at Kosovo, i samråd og nært samarbejde med større lande i Europa samt USA, besluttede at handle uden om FN og erklære, hvad mange har kaldt, samordnet selvstændighed (i modsætning til unilateral selvstændighed). Men det betød også, at Kosovo, der i dag er anerkendt af 90 lande, ikke er medlem af FN. Landet er derfor havnet i den usædvanlige situation, at efter næsten 10 års tålmodig accept, men også megen hjælp af FN/ UNMIK er Kosovo udelukket fra at tage sin plads i den organisation, der hjalp det på vejen mod selvstændighed. Og for at føje spot til skade har FN's Generalforsamling i år valgt som formand den tidligere serbiske udenrigsminister Vuk Jeremic, der sjældent har forsømt en mulighed til at gøre det klart, at Serbien aldrig anerkender Kosovo og 
derfor altid vil modsætte sig Kosovos medlemskab i FN. Det er ikke svært at forestille sig, hvordan Jeremic også vil bruge sit år som formand for Generalforsamlingen til at minde andre lande om Serbiens position på det område.

\section{Fem EU-lande blokerer}

Det er ikke blot FN, der holder Kosovo udenfor. Det gør EU på sin vis også, eftersom fem EU-lande har nægtet at anerkende Kosovos uafhængighed - hovedsageligt på grund af egne mindretalsproblemer og frygt for præcedens ved anerkendelse af Kosovo. Det er bemærkelsesværdigt, at en organisation, der netop er blevet tildelt Nobels fredspris på visse områder må acceptere, at nationale interesser overtrumfer et kollektivt mål om stabilitet på det europæiske kontinent, specielt da Nobelkomiteen brugte som en af sine begrundelser for fredsprisen EU's rolle i stabiliseringen af Vestbalkan. Jeg finder det også interessant i den forbindelse, at de to lande, der står sidst i køen til EU, er Bosnien og Kosovo - de værste ofre for udrensningskonflikterne i halvfemserne og blandt andet af samme grund de lande, der startede genopbygningsprocessen efter konflikterne med de største forhindringer og udfordringer.

Det er svært at normalisere og konsolidere den nye selvstændige status, når Kosovo holdes uden for
FN og har unormale relationer til EU, da 'kun' 22 EU-lande har anerkendt Kosovo. Kosovos fremskridt i integrationsprocessen afhænger naturligvis af konkrete resultater på alle relevante områder i acquis communitaire, men man kan mistænke, at tempoet for fremskridt ikke blot afhænger af Kosovos eget hjemmearbejde, men også af en ekstra kritisk indstilling fra de fem ikke-anerkendende lande til rapporter fra Kosovo.

\section{Regionale problemer}

En yderligere komplikation for normalisering og stabilisering er, at det fortsat er svært for Kosovo på grund af modstand fra Serbien at deltage på lige fod med andre lande i regionale møder i Vestbalkan, hvor specielt samarbejde omkring økonomi og handel er vigtigt for Kosovo.

I den bilaterale dialog mellem Kosovo og Serbien, ledet af EU, er man blevet enige om, at Serbien ikke længere kan blokere Kosovos deltagelse i regionale møder, men på den betingelse, at Kosovo accepterer navneskilte i møderne, der identificerer Kosovo med en asterisk, der henviser både til sikkerhedsresolution 1244, der bragte Kosovo under FN's administration, og til ICJ, den internationale domstol, der for nogle år siden erklærede, at Kosovos erklæring af uafhængighed ikke var i strid med internationale konventioner og normer. 
Jeg er en af de mange, der har udtrykt bekymring over dette kompromis, som blev til på baggrund af enormt pres på Kosovo fra USA og ledende lande i EU. Jeg mener, at en asterisk sætter tiden tilbage til før Kosovos erklæring om uafhængighed, og det var jo Serbiens hensigt, mens Kosovo ikke får meget ud af det kompromis, da Serbien fortsat synes på mange måder at modarbejde Kosovos aktive deltagelse i regionale møder.

Som næunt ovenfor er der mange eksterne faktorer uden for Kosovos kontrol, som arbejder imod normalisering. Men der er også områder under Kosovos kontrol, som man kan gøre noget ved, og det handler om fem prioriteter: udvikle og udbygge demokratiet; arbejde målbevidst på at gøre Kosovo til en retsstat efter europæiske kriterier og i den forbindelse tage konkrete skridt til at bekæmpe korruption og organiseret kriminalitet; opbygge og udvikle en fungerende formel økonomi i stedet for den grå økonomi, der er baseret på ovennæunte korruption, dominerer det økonomiske liv og holder eventuelle investorer på afstand; tage konkrete skridt til at tackle den dramatiske arbejdsløshed blandt Kosovos unge; og at gøre alt nødvendigt hjemmearbejde for at fremme mulighederne for konkrete fremskridt i den europæiske integreringsproces. Lad mig kommentere disse fem prioriteter.

Demokratiet i Kosovo er meget ungt. Styret og kontrollen over Kosovo var i årtier baseret på den Beograd-dirigerede kommunistiske ideologi, bevidst undertrykkelse af den Kosovo-albanske befolkning og voldelig respons på ethvert forsøg på at fremme en Kosovo-albansk identitet.

\section{Tålmodigheden brast}

Den ikke-voldelige protest mod serbisk dominans ledet af Kosovos første præsident, Ibrahim Rugova, bragte ingen nævneværdige forbedringer i dagliglivet for den almindelige Kosovo-albaner, så da UCK startede den voldelige opstand mod Milosevics undertrykkelse og etniske udrensning af Kosovo-albanerne, var det både et udtryk for, at det var slut med tålmodigheden, og et oprør mod det serbiske styre og mod ikkevoldsfilosofien.

UNMIK's administration var i næsten 10 år, inden Kosovo erklærede sig uafhængigt, præget af de stærke modsætninger i mandatet i Sikkerhedsrådets resolution 1244. En af UNMIK's vigtigste opgaver var at fremme lokalt selvstyre, men resolutionen var tavs om formålet med lokalt selvstyre. Det var vel ment som en måde at købe tid på og at administrere en foreløbig løsning.

Da jeg ankom i august 2004, var den lokale tålmodighed omkring 'vent-og-se' politikken næsten udtømt, og det var klart, at vi måtte ændre kurs og sætte processen i gang for at nå frem til en beslutning 
om Kosovos endelige status. Og det var lige så klart, selv om vi ikke kunne sige det, at der intet alternativ var til selvstændighed.

Det medførte den næste modsætning i 1244. Det var mit mandat som FN's Specielle Repræsentant at fremme en proces, der kunne føre til begyndelsen på statusprocessen. Men mit mandat forbød, at vi overførte administrative kompetencer til de lokale myndigheder, der kunne sidestilles med suverænitet. Med andre ord, UNMIK var den øverste ansvarlige autoritet. Kosovos lokale selvstyre var dag til dag ansvarlig, men uden det endelige ansvar for beslutninger eller manglende beslutninger. Det var ikke den bedste måde at forberede personer til inden for kort tid at styre deres eget land.

\section{Winner takes all}

Så det er vel ikke så mærkværdigt, at Kosovos politikere - regeringsmedlemmer, oppositionspolitikere, parlamentsmedlemmer, kommunalpolitikere - var dårligt forberedte til at stå på egne ben, og heller ikke så besynderligt, at de længe har søgt råd og hjælp hos de internationale repræsentanter i Kosovo. Men samtidig er indstillingen til demokrati fortsat meget umoden.

Der råder en 'winner-takes-all' mentalitet, og politiske beslutninger vurderes ikke så meget $\mathrm{i}$ lyset af, om de tjener nationen, men mere om de scorer partipolitiske point. Pro- ces og kortsigtede egoistiske interesser kommer i første række, substans i anden række. Til forsvar for det demokratiske underskud må man naturligvis acceptere den meget korte tid, Kosovo politisk har været selvstændigt, og sammenligne med nogle lande i Centraleuropa, der ikke er kommet meget længere. Men man må håbe, at det ikke er for sent for denne generations politikere at lære demokratiets spilleregler.

Den anden prioritet er, at Kosovos politiske ledere bevæger sig fra ord til handling i bekæmpelsen af organiseret kriminalitet og korruption. Politikerne forsikrer konstant offentligheden og internationale repræsentanter om deres stærke hensigter til at bekæmpe korruptionen. På den anden side har vi endnu ikke oplevet retsforfølgelse og dom af en eneste højt placeret politiker.

EULEX, EU's mission til at udvikle retssystemet, har gang på gang bedyret, at man var tæt på at sigte og retsforfølge prominente Kosovopolitikere og erhvervsfolk, men man venter fortsat på den første fuldendte sag og domfældelse. I november blev det dog meddelt, at den første formelle sigtelse for korruption nu er rejst med en højt placeret politiker.

Jeg må dog nævne her, at det heller aldrig lykkedes UNMIK at opnå konkrete resultater af vores gode intentioner og hårde arbejde $\mathrm{i}$ bekæmpelsen af korruption. Enten er 
grunden, at internationale repræsentanter ikke er dygtige nok, eller også er grunden, at når det kommer til at dække over korruption og organiseret kriminalitet, arbejder de lokale myndigheder og foretagender tværs over partipolitiske grænser for at beskytte hinanden og ikke risikere, at nogen begynder at tale om de mange lyssky aktiviteter.

Kosovo har brug for en ledende politiker, der sætter nationens interesse over alt andet, og det kræver, at man kommer korruptionen til livs. Uden dette vil demokratiet altid have svære kår og økonomien lige så vanskeligt ved at vokse.

\section{Den grå økonomi}

Netop økonomisk vækst er den tredje prioritet. Jeg sagde ofte privat under min tid i Kosovo, at det var vanskeligt at beklage den 'grå' $\emptyset$ konomi, for uden den var der ingen økonomi i det hele taget.

Meget lidt har ændret sig siden uafhængighedserklæringen. Kosovo producerer meget lidt, men spenderer mere, end det tjener, og overhører ofte gode råd og formaninger fra den Internationale Valutafond om ansvarlig økonomisk politik. Endvidere er det naturligvis vanskeligt at forestille sig, at private investorer i tilstrækkeligt antal vil finde vej til et land, hvis status er uklar og hvor der stadigvæk er lang vej til en fungerende retsstat efter europæiske mønstre. Selv mange af Kosovos nærmeste venner, den store diaspora i USA og Europa, har ofte opgivet at investere i deres eget fædreland efter at have stødt panden mod muren af bureaukrati, nepotisme og korruption.

Mine mange kontakter med diasporaen og mine hyppige møder med almindelige kosovarer rundt omkring i landet har overbevist mig om, at Kosovo har alle forudsætninger for at lykkes økonomisk. De er talentfulde, hårdt arbejdende og diasporaen har skabt store, produktive foretagender i både USA og Europa.

Derudover sidder Kosovo på store energiforekomster, som med de rette investeringer og ledelse kombineret med miljøvenlige processer kunne gøre Kosovo til nettoeksportør og selvforsynende på energiområdet. Indtil videre må det blive de små foretagender plus den betydelige hjemsendelse af penge fra kosovarer uden for landet, der hjælper mange mennesker til at klare dagen og vejen, men ikke mere.

\section{Katastrofal jobmangel}

Den fjerde prioritet, som er knyttet direkte til den kritiske økonomiske situation, er at tackle den katastrofale arbejdsløshed og de manglende fremtidsudsigter blandt Kosovos ungdom. Arbejdsløsheden for befolkningen som sådan ligger på omkring 50 pct., for ungdommen endnu højere. Det har ofte undret mig, 
at de unge er så passive og tilsyneladende accepterer, at de politiske ledere ofte synes mere interesseret $i$ at fremme deres egne partipolitiske eller personlige interesser end nationens velfærd i almindelighed og ungdommens trivsel i særdeleshed. Det arabiske forår synes ikke at have gjort noget indtryk i Kosovo. Apati og manglende tillid til politikerne har handlingslammet de unge i Kosovo, og det er naturligvis et alvorligt problem både på kort og længere sigt.

Der er ingen tvivl om, at mange unge kun venter på den dag, hvor Kosovo bliver en del af den frie bevægelighed i EU-landene. Det kan være en kortsigtet løsning, da det mindsker det eventuelle pres på den politiske situation, som på et eller tidspunkt må komme fra de unge.

Og det kan måske også hjælpe med demokratiseringen og opbygningen af retsstaten, hvis de unge kosovarer oplever demokrati og retssystemet i virkeligheden i lande rundt omkring i Europa. Mange vender forhåbentlig hjem igen med kvalifikationer og ideer om, hvordan man kan udvikle det nye Kosovo, tiltrække investeringer og uddanne den næste generation til at fungere i et moderne europæisk samfund.

Det er netop den sidste og måske vigtigste prioritet, den europæiske fremtid, der kan give Kosovo de nødvendige mål og retningslinjer for at nå målet. Jeg har personligt oplevet, hvordan et realistisk håb om en fremtid i frihed og selvstændighed, da vi stillede begyndelsen på statusforhandlinger i udsigt, forudsat at Kosovo opfyldte en række kriterier - vi kaldte dem standards kunne motivere mange politikere og almindelige mennesker til seriøs handling og hårdt arbejde.

Et europæisk perspektiv burde i endnu højere grad animere politiske ledere til at udarbejde en vision, en strategi, og en handlingsplan for landet og dets befolkning. Og det burde også være klart, at det europæiske perspektiv er Kosovos perspektiv og ikke en partipolitisk sag alene. Da vi nærmede os begyndelsen på statusforhandlingerne, fik vi efter mange anstrengelser partilederne af de fire største partier til at gå sammen med præsidenten og statsministeren i et 'Enhedsteam'.

Ahtisaari nævnte ofte, hvor imponeret han havde været af Kosovos indstilling til og indsats i statusforhandlingerne. Ganske givet fordi de politiske ledere og partier samarbejdede for at nå det forjættede mål, selvstændighed. I dag har mange iagttagere ofte indtryk af, at der i den politiske verden i Kosovo bruges mere tid på at bekæmpe hinanden end på at fremme Kosovos interesser.

\section{Kosovo i Europa}

$\mathrm{Nu}$ er tiden kommet til at kaste snævertsynede interesser til side og 
samle nationen omkring det overordnede mål, Kosovos integration i Europa. Politiske ledere må være ærlige og fortælle befolkningen, at vejen er lang, og at målet kun nås gennem hårdt arbejde, opfyldelse af Europas mange kriterier og specielt opbygningen af en retsstat og bekæmpelsen af korruption og organiseret kriminalitet.

På den anden side må EU også hjælpe Kosovo på vej. EU's operation i Kosovo, EULEX, der har til formål at hjælpe Kosovo med at opbygge retsstaten og bekæmpe korruption og organiseret kriminalitet, har indtil nu opnået meget beskedne resultater. Samtidig er den rolle, EU spiller som formidler af dialogen mellem Kosovo og Serbien, vigtig. Eventuel fremgang i integrationsprocessen er guleroden for begge parter.

Kosovo har en klar interesse i normale relationer med Serbien, der kan bidrage til regional samhandel og fjerne en af de vigtigste forhindringer for investeringer i Kosovo usikkerhed om status og frygt for nye konflikter. Og Serbien må forstå, at normalisering i relationerne med Kosovo og stop for destabiliserende retorik og handlinger i Kosovo er klare betingelser for medlemskab i EU.

Gennem årene har det ofte været USA, der har spillet den afgørende rolle i at stoppe konflikterne i Vestbalkan, og det var bemærkelsesværdigt, at det igen var en amerikansk politiker, denne gang udenrigsminister Hillary Clinton, der under et nyligt besøg i regionen med EU's udenrigschef Catherine Ashton gjorde det klart, at "...Grænserne i et uafhængigt, suverænt Kosovo er klare og fastlagte ... det er ikke til diskussion...".

$\mathrm{Nu}$ er det op til EU at være lige så klar og utvetydig, når dialogen mellem Kosovo og Serbien genoptages.

Søren Jessen-Petersen var FN's generalsekreters sarlige representant $i$ Kosovo 2004-06. Bestred tidligere internationale poster $i$ Bosnien $\mathcal{E}$ Hercegovina og Makedonien for $E U$. 